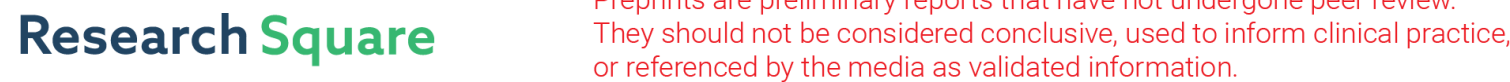 \\ Preparation of Tree-Structured ZnO Films And Application In Quantum Dots Sensitized Solar Cells
}

\section{Shaokang Dong}

Henan University

Shengjun Li ( $\sim$ lishengjun1011@126.com )

Henan University

Junhao Cai

Henan University

\section{Zeng Chen}

Henan University

\section{Fuhao Sun}

Henan University

\section{Pin Lv}

Henan University

\section{Nano Express}

Keywords: Zinc oxide, quantum-dot-sensitized solar cells, tree-structured films, hydrothermal method

Posted Date: August 6th, 2021

DOl: https://doi.org/10.21203/rs.3.rs-735371/v1

License: (c) (i) This work is licensed under a Creative Commons Attribution 4.0 International License. Read Full License 


\section{Abstract}

This study reported the fabrication of tree-structured $\mathrm{ZnO}$ films through hydrothermal method. Long $\mathrm{ZnO}$ nanowires (NWs) were firstly deposited on the transparent conductive glass substrates. ZnO braches were then grown on the surface of $\mathrm{ZnO} \mathrm{NWs}$. The morphology of the as-prepared tree-structured $\mathrm{ZnO}$ films was affected by several factors, such as the concentration of $\mathrm{Zn}\left(\mathrm{CH}_{3} \mathrm{COO}\right)_{2}$ in the seed precursor solution, and the hydrothermal reaction time. ZnO branches were vertically grown on the ZnO NWs when the concentration of $\mathrm{Zn}\left(\mathrm{CH}_{3} \mathrm{COO}\right)_{2}$ was $0.04 \mathrm{M}$. Quantum dots (QDs)-sensitized solar cells were assembled using the CdS/CdSe QDs co-sensitized ZnO films as the photoanodes. The value of Incident photon-to-current conversion efficiency (IPCE) in the range of 550-650 nm was obviously enhanced with the growth of $\mathrm{ZnO}$ braches. The short-circuit current density $\left(J_{\mathrm{SC}}\right)$ was increased from 9.65 to $12.60 \mathrm{~mA}$ $\mathrm{cm}^{-2}$ when the growth time of $\mathrm{ZnO}$ branches was $6 \mathrm{~h}$. The overall PCE increased from $3.21 \%$ to $5.19 \%$.

\section{Introduction}

In the past few years, quantum-dot-sensitized solar cells (QDSCs) have attracted immense scientific and technological interest because of their advantages, such as simple preparation process, costeffectiveness, and high power conversion efficiency (PCE) [1-4]. The PCE of QDSCs has been improved to be $14.4 \%$, which is comparable with those of other solar cells $[5,6]$. There are three main parts in QDSCs, photoanode, electrolyte, and the counter electrode parts $[7,8]$. The photoanode is the key section of QDSCs which is responsible for the light capture and the generation of electrons [9-11]. The photoanodes have been prepared based on different oxide semiconductors with wide band gap. ZnO is an important environment-friendly, cost-effective n-type semiconductor material which has a high electron mobility $\left(200-1000 \mathrm{~cm}^{2} \mathrm{~V}^{-2} \mathrm{~s}^{-1}\right)[12,13]$. At the same time, the morphology of $\mathrm{ZnO}$ could be easily controlled using various methods. Various nanostructures of $\mathrm{ZnO}$, such as nanorods (NRs), nanosheets (NSs), nanowires, nanoflowers, and nanoballs, have been successfully prepared and applied in solar cells [14-16].

ZnO nanorods were widely studied in QDSCs because the 1D crystalline nanostructured ZnO could provide a direct conduction pathway for the photogenerated electrons. However, the surface area of the ZnO NRs film was much lower than the conventional nanoporous $\mathrm{TiO}_{2}$ films used in QDSCs. To further enhance the surface area of ZnO NRs film, various nanostructures were prepared on ZnO NRs. Deng et al. prepared $\mathrm{TiO}_{2}$ nanoparticles and $\mathrm{ZnO}$ nanowires hybrid photoanodes which improved the light-trapping of photoanode due to the strong light scatting effect of ZnO NWs [17]. Tian et al. have prepared ZnO NRNS-structured film by adjusting the growth orientation of the $\mathrm{ZnO}$ crystals in the reaction solution. The power conversion efficiency exhibits one-time improvement compared with that of pure ZnO NRs photoanodes [18]. Ko et al prepared high density, long branched "treelike" multigeneration hierarchical $\mathrm{ZnO}$ nanowire photoanodes [19]. Generally, hierarchical nanostructured ZnO films exhibit better properties compared to single-structured $\mathrm{ZnO}$ films. However, it was challenging to control the morphology of the second ZnO nano-layer on ZnO NWs. In this experiment, ZnO NWs were firstly deposited on FTO 
substrates using the hydrothermal method, and $\mathrm{ZnO}$ branches were vertically grown on the primary $\mathrm{ZnO}$ NWs. The tree-structured ZnO films were co-sensitized with CdS and CdSe QDs to prepare photoanodes for QDSCs. A power conversion efficiency of approximately 5.19\% was obtained.

\section{Experimental}

\subsection{Materials}

Zinc nitrate hexahydrate $\left(\mathrm{Zn}\left(\mathrm{NO}_{3}\right)_{2} \cdot 6 \mathrm{H}_{2} \mathrm{O}\right)$, zinc acetate $\left(\mathrm{Zn}\left(\mathrm{CH}_{3} \mathrm{COO}\right)_{2}\right)$, monoethanolamine $\left(\mathrm{HO}\left(\mathrm{CH}_{2}\right)_{2} \mathrm{NH}_{2}\right)$, hexamethylenetetramine $\left(\mathrm{C}_{6} \mathrm{H}_{12} \mathrm{~N}_{4}\right)$, cadmium nitrate tetrahydrate $\left(\mathrm{Cd}\left(\mathrm{NO}_{3}\right)_{2} \cdot 4 \mathrm{H}_{2} \mathrm{O}\right)$, sodium thiosulfate $\left(\mathrm{Na}_{2} \mathrm{~S}_{2} \mathrm{O}_{3}\right)$, cadmium sulfate $\left(\mathrm{CdSO}_{4}\right)$, trisodium nitrilotriacetate monohydrate $\left(\mathrm{C}_{6} \mathrm{H}_{6} \mathrm{NNa}_{3} \mathrm{O}_{6} \cdot \mathrm{H}_{2} \mathrm{O}\right)$, and sodium sulfide $\left(\mathrm{Na}_{2} \mathrm{~S}\right)$ were purchased from Sinopharm Chemical Reagent Co. (SCRC, China). Ethanol and methanol (purities $>99.9 \%$ ) were purchased from Aladdin Reagent Co. (China). All of these materials were used as received without any further purification.

\section{2 preparation of tree-structured $\mathrm{ZnO}$ films}

For the preparation of $\mathrm{ZnO} \mathrm{NWs}$, a thin $\mathrm{ZnO}$ seed layer were firstly deposited on glass substrates according to the former studies [20]. Long ZnO NWs were grown through hydrothermal reaction at $95{ }^{\circ} \mathrm{C}$ in a high pressure reactor. The primary precursors were zinc nitrate $\left(\left(\left(\mathrm{Zn}\left(\mathrm{NO}_{3}\right)_{2}\right), 4 \mathrm{mM}\right)\right.$ and hexamethylenetetramine (HMTA: $\mathrm{C}_{6} \mathrm{H}_{12} \mathrm{~N}_{4}, 4 \mathrm{mM}$ ) with polyethylenemine $\left(\mathrm{PEI},\left(\mathrm{C}_{2} \mathrm{H}_{5} \mathrm{~N}\right)_{n}\right)$ as additive chemicals in the solution. The hydrothermal reaction time is controlled to be $24 \mathrm{~h}$. The former hydrothermal reaction processes were repeated for the preparation of longer $\mathrm{ZnO}$ NWs. The detailed experiments were described in the former studies [20]. The prepared $\mathrm{ZnO} N W s$ were immersed in an ethanol solution containing $\mathrm{Zn}\left(\mathrm{CH}_{3} \mathrm{COO}\right)_{2}$. Then, the $\mathrm{ZnO}$ NWs samples were hanged in deionized water solution which consisted of $0.05 \mathrm{~mol} / \mathrm{L} \mathrm{Zn}\left(\mathrm{NO}_{3}\right)_{2}$ and $0.04 \mathrm{~mol} / \mathrm{L} \mathrm{C}_{6} \mathrm{H}_{12} \mathrm{~N}_{4}$ under $90{ }^{\circ} \mathrm{C}$ to grow $\mathrm{ZnO}$ branches on the former prepared NWs. The growth time was controlled to be 1, 6, 12 and $24 \mathrm{~h}$. The obtained tree-structured $\mathrm{ZnO}$ films were dried under room temperature and sintered at $450{ }^{\circ} \mathrm{C}$ in muffle furnace.

\subsection{Sensitization of tree-structured ZnO films and QDSCs fabrication}

CdS QDs were firstly deposited on the tree-structured $\mathrm{ZnO}$ films through successive ion layer absorption and reaction technique (SILAR) method. The detailed processes were performed following the former studies [21]. For the deposition of CdSe QDs, the CdS sensitized tree-structured $\mathrm{ZnO}$ films were then immersed in a mixed aqueous solution containing $\mathrm{Na}_{2} \mathrm{SeSO}_{3}, \mathrm{CdSO}_{4}$, and $\mathrm{C}_{6} \mathrm{H}_{6} \mathrm{NNa}_{3} \mathrm{O}_{6}$ for ca. $4 \mathrm{~h}$ at room temperature. The CdS and CdSe QDs co-sensitized ZnO films were rinsed with DI water and dry at room temperature in dark.

The CdS and CdSe QDs co-sensitized ZnO films were used as photoanodes. PbS films, which were prepared through the treatment of $\mathrm{Pb}$ sheets in a $2.0 \mathrm{M}$ of $\mathrm{Na}_{2} \mathrm{~S}, 0.5 \mathrm{M}$ of $\mathrm{S}$, and a $0.2 \mathrm{M} \mathrm{KCl}$ mixed 
solution for another $1 \mathrm{~h}$ at $70{ }^{\circ} \mathrm{C}$, were used as the counter electrodes. The electrolyte was polysulfide aqueous solution containing $1 \mathrm{M}$ of $\mathrm{Na}_{2} \mathrm{~S}, 1 \mathrm{M}$ of $\mathrm{S}$, and $0.1 \mathrm{M}$ of $\mathrm{NaOH}$. The photoanodes and $\mathrm{PbS}$ counter electrodes were sandwiched to be a simple solar cell device.

\subsection{Measurement and characterization}

The morphology and structure of the tree-structured $\mathrm{ZnO}$ films were characterized through field-emission scanning electron microscopy (FE-SEM, JSM-7001F). The crystalline phase of the samples was examined using X-ray diffraction (XRD, DX-2700) with a monochromatic $\mathrm{Cu} \mathrm{K}_{\mathrm{a}}$ irradiation $(\lambda=0.154145$ $\mathrm{nm})$.

The photovoltaic performance of QDSCs was measured using a Keithley 2440 source meter under AM 1.5G illumination from a Newport Oriel solar simulator with an intensity of 1 Sun. The incident light intensity was calibrated using a standard Si solar cell obtained from Newport Oriel. The active cell area of the assembled QDSCs was $0.25 \mathrm{~cm}^{2}$. Incident photon-to-current conversion efficiency (IPCE) spectra were recorded on an IPCE system especially designed for QDSCs (Crowntech. Inc.). To generate a monochromatic beam, a 150-W tungsten halogen lamp was used as the light source. A silicon solar cell was used as the standard during calibration. IPCE values were measured using a Keithley model 2400 source meter.

\section{Results And Discussion}

Regular ZnO NWs were mostly vertically grown on the FTO glass substrate. The length of the NWs could be regulated to be ca. 3.08, 6.27 and $11.3 \mu \mathrm{m}$, respectively (shown in Fig.1), with the extension of the hydrothermal reaction times. The hydrothermal reaction time was $24 \mathrm{~h}$ for one growth processes. So the growth time of the ZnO NWs were controlled to be $24 \mathrm{~h}, 48 \mathrm{~h}$ and $72 \mathrm{~h}$. It also can be seen that there were almost no dividing lines in the whole $\mathrm{ZnO}$ NWs in Fig. 1(c) although the ZnO NWs were grown through three times of hydrothermal reaction. At the same time, there were large distance between the adjacent $\mathrm{ZnO}$ NWs, which provided convenience for the growth of $\mathrm{ZnO}$ branches.

For the growth of $\mathrm{ZnO}$ branches on the NWs,the obtained $\mathrm{ZnO}$ NWs films were immersed in the $\mathrm{ZnO}$ seed solution containing $1.2 \mathrm{M} \mathrm{Zn}\left(\mathrm{CH}_{3} \mathrm{COO}\right)_{2}$ and sintered at $450{ }^{\circ} \mathrm{C}$ for $30 \mathrm{~min}$. Then, the $\mathrm{ZnO} \mathrm{NWs}$ was hanged in the solution containing $0.05 \mathrm{~mol} / \mathrm{L} \mathrm{Zn}\left(\mathrm{NO}_{3}\right)_{2}$ and $0.04 \mathrm{~mol} / \mathrm{L} \mathrm{C}_{6} \mathrm{H}_{12} \mathrm{~N}_{4}$ under $90{ }^{\circ} \mathrm{C}$. The time of the hydrothermal treatment was controlled to be 1,6 and $12 \mathrm{~h}$, respectively. Figure 2 shows the surface and cross section of the tree-structured $\mathrm{ZnO}$ films after different hydrothermal treatment time. There were some short branches grown on the surface of the $\mathrm{ZnO}$ NWs when the hydrothermal treatment time was 1 h. The short branches were ca. $100 \mathrm{~nm}$. The length of the branches was improved to be ca. $500 \mathrm{~nm}$ when the hydrothermal treatment time was $6 \mathrm{~h}$. The length of the branches was further increased to be ca. 1.0 $\mu \mathrm{m}$ after $12 \mathrm{~h}$ hydrothermal treatment. The length of $\mathrm{ZnO}$ branches depended on the hydrothermal treatment time. It can also be seen from the cross section of these samples that the $\mathrm{ZnO}$ branches were 
almost grown surrounding the $\mathrm{ZnO} \mathrm{NWs}$. However, there were few $\mathrm{ZnO}$ branches at the end of $\mathrm{ZnO}$ NWs. This phenomenon might be related with the capillary effect during the immersion process of $\mathrm{Zn}$ seeds.

Though $\mathrm{ZnO}$ branches could grow at the surface of $\mathrm{ZnO}$ NWs, the $\mathrm{ZnO}$ branches were much messy. In this experiment, it was investigated about the effects of the concentration of $\mathrm{Zn}\left(\mathrm{CH}_{3} \mathrm{COO}\right)_{2}$ in the $\mathrm{ZnO}$ seed solution on the morphologies of the $\mathrm{ZnO}$ films. The concentration of $\mathrm{Zn}\left(\mathrm{CH}_{3} \mathrm{COO}\right)_{2}$ was increased from 1.2 $\mathrm{M}$ to 2.4 M. The branches became more dense and chaotic (shown in Fig. 3 (a-d)). The branches were ca. $500 \mathrm{~nm}$ in length. The concentration of $\mathrm{Zn}\left(\mathrm{CH}_{3} \mathrm{COO}\right)_{2}$ was also decreased to $0.24 \mathrm{M}$ and $0.04 \mathrm{M}$. It can be seen from the SEM images (Fig. S1 and Fig. 3 (e) and (f)) that the length of branches increased with the decreasing of the concentration of $\mathrm{Zn}\left(\mathrm{CH}_{3} \mathrm{COO}\right)_{2}$. Meanwhile, the branches were mostly vertical to the $\mathrm{ZnO} N W s$ when the concentration of $\mathrm{Zn}\left(\mathrm{CH}_{3} \mathrm{COO}\right)_{2}$ was $0.04 \mathrm{M}$. The length of the branches was over $1 \mu \mathrm{m}$.

The obtained $\mathrm{ZnO}$ NWs films and tree-structured $\mathrm{ZnO}$ films were co-sensitized with $\mathrm{CdS}$ and CdSe quantum dots. The sensitized $\mathrm{ZnO}$ films were assembled with $\mathrm{PbS}$ counter electrode as Sandwichstructured solar cells. Figure 4 (a) and (b) show the photovoltaic characteristics of these quantum dots sensitized solar cells. The characteristic parameters were summarized in Table1. It can be seen from Fig.4 (a) that the short-circuit current density $\left(J_{S C}\right)$ increased with the lengthening of the growth time of $\mathrm{ZnO}$ NWs. The improvement of $J_{\mathrm{SC}}$ should be due to the increase of quantum dots deposited on the $\mathrm{ZnO}$ NWs. Meanwhile, the fill factor $(F F)$ and open-circuit voltage $\left(V_{\mathrm{OC}}\right)$ also was enhanced with the lengthening of the growth time. The specific surface area of the $\mathrm{ZnO}$ films should be further improved with the growth of $\mathrm{ZnO}$ branches. On the other hand, the growth of branches might increase the diffuse reflection properties of these $\mathrm{ZnO}$ films. The former two effects were both benefit to the increase of $J_{\mathrm{SC}}$ of the quantum dots sensitized solar cells. Figure4 (b) shows the photocurrent density-voltage of the CdS and CdSe quantum dots co-sensitized tree-structured $\mathrm{ZnO}$ films. It can be seen that the main parameters of QDSCs, such as $J_{\mathrm{SC}}, V_{\mathrm{OC}}$ and $F F$, were all obviously enhanced with the growth of $\mathrm{ZnO}$ branches. The $J_{S C}$ was increased from 9.65 to $12.60 \mathrm{~mA} \mathrm{~cm}^{-2}$ when the growth time of $\mathrm{ZnO}$ branches was $6 \mathrm{~h}$. Meanwhile, the fill factor and open-circuit voltage were increased to be $676 \mathrm{mV}$ and 0.61 , respectively. The overall PCE increased from 3.21-5.19\%. The fill factor and open-circuit voltage showed almost no changes when the growth time of $\mathrm{ZnO}$ branches was further increased. However, the value of $J_{S C}$ began to decrease when the growth time of $\mathrm{ZnO}$ branches was further increased. So the optimum growth time of $\mathrm{ZnO}$ branches should be ca. $6 \mathrm{~h}$. 
Table 1

Photovoltaic characteristics of the QDSCs using CdS-CdSe quantum-dot-sensitized ZnO NWs and treestructured ZnO films films as photoanodes

\begin{tabular}{|llllll|}
\hline $\begin{array}{l}\text { Growth time of ZnO } \\
\text { NWs }\end{array}$ & $\begin{array}{l}\text { Growth time of ZnO } \\
\text { branches }\end{array}$ & $\begin{array}{l}J_{\mathrm{Sc}} / \mathrm{mA} \mathrm{cm}^{-} \\
2\end{array}$ & $V_{\mathrm{OC}} / \mathrm{mV}$ & $F F$ & $P C E / \%$ \\
\hline $24 \mathrm{~h}$ & 0 & 7.79 & 567 & 0.45 & 2.06 \\
\hline $48 \mathrm{~h}$ & 0 & 8.69 & 586 & 0.49 & 2.46 \\
\hline $72 \mathrm{~h}$ & 0 & 9.65 & 595 & 0.56 & 3.21 \\
\hline $72 \mathrm{~h}$ & $1 \mathrm{~h}$ & 10.20 & 648 & 0.59 & 3.89 \\
\hline $72 \mathrm{~h}$ & $6 \mathrm{~h}$ & 12.60 & 676 & 0.61 & 5.19 \\
\hline $72 \mathrm{~h}$ & $12 \mathrm{~h}$ & 11.75 & 683 & 0.60 & 4.81 \\
\hline $72 \mathrm{~h}$ & $24 \mathrm{~h}$ & 10.81 & 682 & 0.62 & 4.57 \\
\hline
\end{tabular}

Fig. 4 (c) and (d) show the IPCE spectrum of the solar cells, assembled with the CdS and CdSe quantum dots co-sensitized ZnO NWs films and tree-structured $\mathrm{ZnO}$ films. It can be seen from Fig. 4 (c) that the IPCE in the range of 350-550 nm was increased with the lengthening of the growth time of ZnO NWs. However, the growth of ZnO branches showed effects on the value of IPCE in the range of 350-650 nm (the whole entire extinction range of the assembled solar cells). The most important effect should be the IPCE in the range of 550-650 nm which was fine supplement to the CdS and CdSe quantum dots cosensitized ZnO NWs films. The results of IPCE gave a good explanation for the improvement of photoelectric conversion performance of the solar cells based on tree-structured $\mathrm{ZnO}$ films.

\section{Conclusions}

ZnO NWs were deposited on transparent conductive glass substrates. The length of $\mathrm{ZnO} N W s$ was ca. $11.3 \mu \mathrm{m}$ after three times of hydrothermal processes. ZnO NWs films were treated in the $\mathrm{ZnO}$ seed solution containing $\mathrm{Zn}\left(\mathrm{CH}_{3} \mathrm{COO}\right)_{2}$ and ethanolamine for the growth of $\mathrm{ZnO}$ braches. The concentration of $\mathrm{Zn}\left(\mathrm{CH}_{3} \mathrm{COO}\right)_{2}$ and treating time were the key parameters which affect the morphology of $\mathrm{ZnO}$ braches. The branches were mostly vertical to the $\mathrm{ZnO} N W s$ when the concentration of $\mathrm{Zn}\left(\mathrm{CH}_{3} \mathrm{COO}\right)_{2}$ was $0.04 \mathrm{M}$. The length of the branches was over $1 \mu \mathrm{m}$. However, the $\mathrm{ZnO}$ braches became more and more disorderly with the increasing of the concentration of $\mathrm{Zn}\left(\mathrm{CH}_{3} \mathrm{COO}\right)_{2}$ in the $\mathrm{ZnO}$ seed solution. The obtained $\mathrm{ZnO}$ NWs films and tree-structured $\mathrm{ZnO}$ films were co-sensitized with CdS and CdSe quantum dots and assembled with PbS counter electrode as Sandwich-structured solar cells. The value of IPCE in the range of 550-650 nm was obviously enhanced with the growth of $\mathrm{ZnO}$ braches. As a result, the $J_{S C}$ was increased from 9.65 to $12.60 \mathrm{~mA} \mathrm{~cm}^{-2}$ when the growth time of $\mathrm{ZnO}$ branches was $6 \mathrm{~h}$. The overall PCE increased from $3.21-5.19 \%$.

\section{Declarations}




\section{Author's contributions}

Shaokang Dong carried out the experiment. Zeng Chen analyzed the data and finished figures in the manuscript. Shengjun Li, Junhao Cai, and Pin Lv provided useful suggestions to the experiment. All authors read and approved the final manuscript.

\section{Declaration of Competing Interest}

The authors declare that they have no known competing financial interests or personal relationships that could have appeared to influence the work reported in this paper.

\section{Acknowledgments}

This work was supported by the Program for Science and Technology Innovation Talents in Universities of Henan Province (18HASTIT031).

\section{References}

[1] P.V. Kamat, J. Phys. Chem. C 112 (2008) 18737-18753.

[2] Y.L. Lee, Y.S. Lo, Adv. Funct. Mater.19 (2009) 604-609.

[3] P.K. Santra, P.V. Kamat, J. Am. Chem. Soc.134 (2012) 2508-2511.

[4] J. Dun, Z.L. Du, J.S. Hu, Z.X. Pan, Q, Shen, J.K. Sung, D.H. Long, H. Dong, L.T. Sun, X.H. Zhong, J. Am. Chem. Soc. 138 (2016) 4201-4209.

[5] H. Song, Y. Lin, M.S. Zhou, H.S. Rao, Z.X. Pan, X.H. Zhong, Angew.Chem. Int. Ed., 60 (2021) 61376144.

[6] W. Wang, W. Feng, J. Du, W. Xue, L. Zhang, L. Zhao, Y. Li, X. Zhong, Adv. Mater. 30 (2018) 1705746.

[7] A. Sahu, A. Garg, A. Dixit, Solar Energy, 203 (2020) 210-239.

[8] M.B.R. Prasad, P.S. Tamboli, V.P. Bhalekar, V. Kadam, J.T. Abraham, C. Rajesh, H.M. Pathan, Mater. Res. Express, (2018) 066208.

[9] J. Liu, C.L. Wang, Z.W. Ge, T. Wang, L.X. Xia, Y.H. Wu, N. Du, H.D. Xiao, J.Q. Liu, Opt. Mater., 107 (2020) 110059.

[10] P. Venkatachalam, S. Rajalakshmi, Mater. Today 22 (2020) 400-403.

[11] C. Zhang, J.H. Zeng, Y.F. Wang, Chem. Phys. Lett., 761 (2020) 138099.

[12] J. Xu, Z. Chen, J.A. Zapien, C.S. Lee, W.J. Zhang, Adv. Mater. 26 (2014) 5337-5367. 
[13] J.A. Anta, E. Guillen, R. Tena-Zaera, J. Phys. Chem. C 116 (2012) 11413-11425

[14] K.Y. Yan, J. Am. Chem. Soc. 135 (2013) 9531-9539.

[15] D.P. Wu, X.L. Wang, K. Cao, Y.P. An, X.H. Song, N. Liu, F. Xu, Z.Y. Gao, K. Jiang, Electrochim. Acta 231 (2017) 1-12.

[16] M. Ramya, T.K. Nideep, V.P.N. Nampoori, M. Kailasnath, J. Mater. Sci.-Mater. El., (2021) DOI: 10.1007/s10854-021-06319-1.

[17] J.P. Deng, M.Q. Wang, C.G. Yang, J. Liu, X.H. Song, RSC Adv. 4 (2014) 41141-41147.

[18] J.J. Tian, E. Uchaker, Q.F. Zhang, G.Z. Cao, ACS Appl. Mater. Interfaces 6 (2014) 4466-4472.

[19] S.H. Ko, D. Lee, H.W. Kang, K.H. Nam, J.Y. Yeo, S.J. Hong, C.P. Grigoropoulos, H.J. Sung, Nano Lett., 11 (2011) 666-671.

[20] S.V. Kurudirek, K.C. Prade, C.J. Summers, J. Alloys Comp., 702 (2017) 700e709.

[21] S.J. Li, Z. Chen, T. Li, H.P. Gao, C.C. Wei, W. Li, W.P. Kong, W.F. Zhang, Electrochim. Acta 127 (2014) 362-368.

Figures 

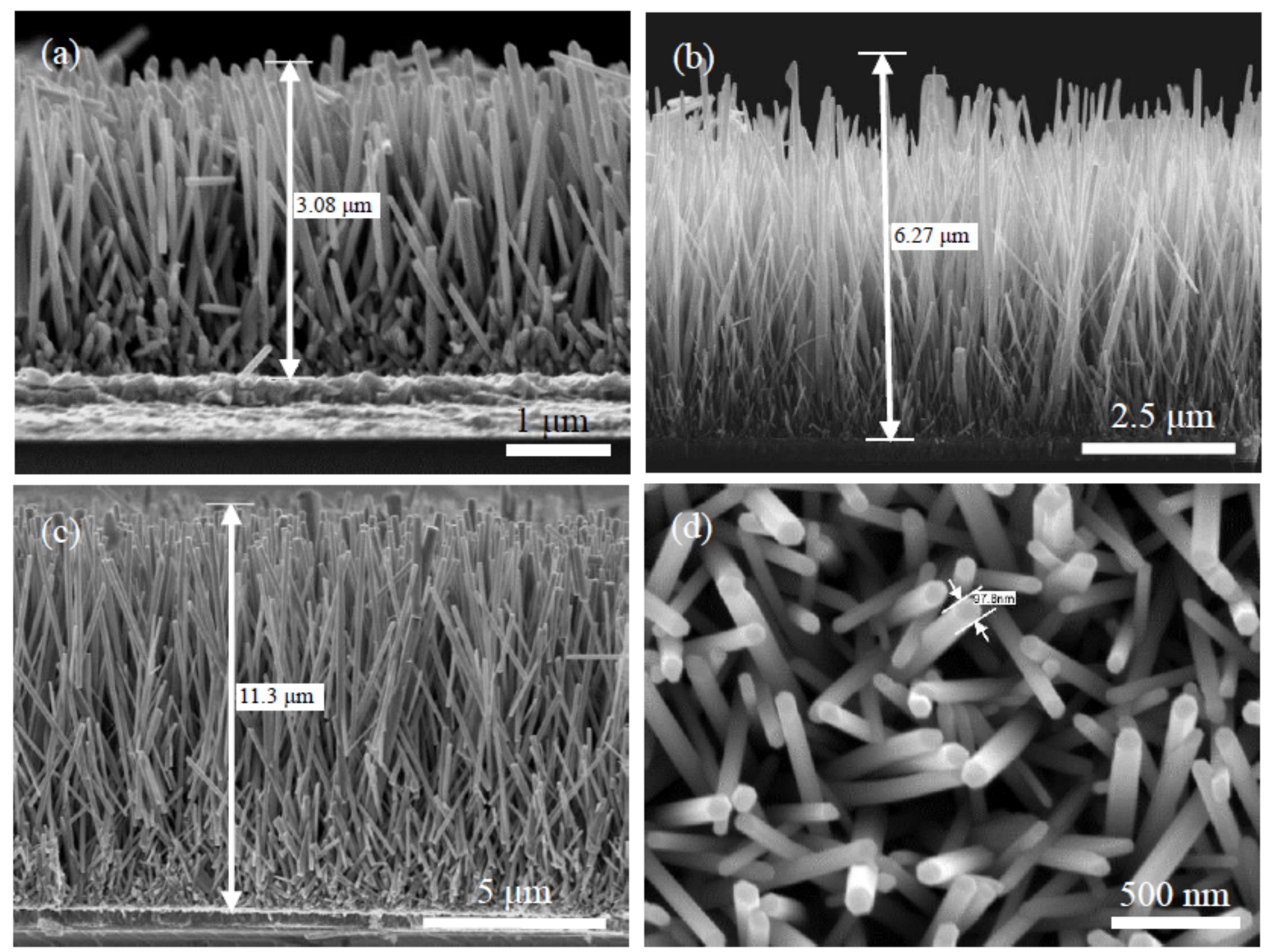

Figure 1

SEM images of $\mathrm{ZnO}$ nanowires grown from the solution of $4 \mathrm{mM} \mathrm{Zn(NO3)2,} 4 \mathrm{mM}$ HMT and $3 \mathrm{mM}$ PEl: (a) growth growth for 1 cycle, (b) growth for 2 cycles, (c) growth for 3 cycles and (d) surface images of ZnO nanowires 

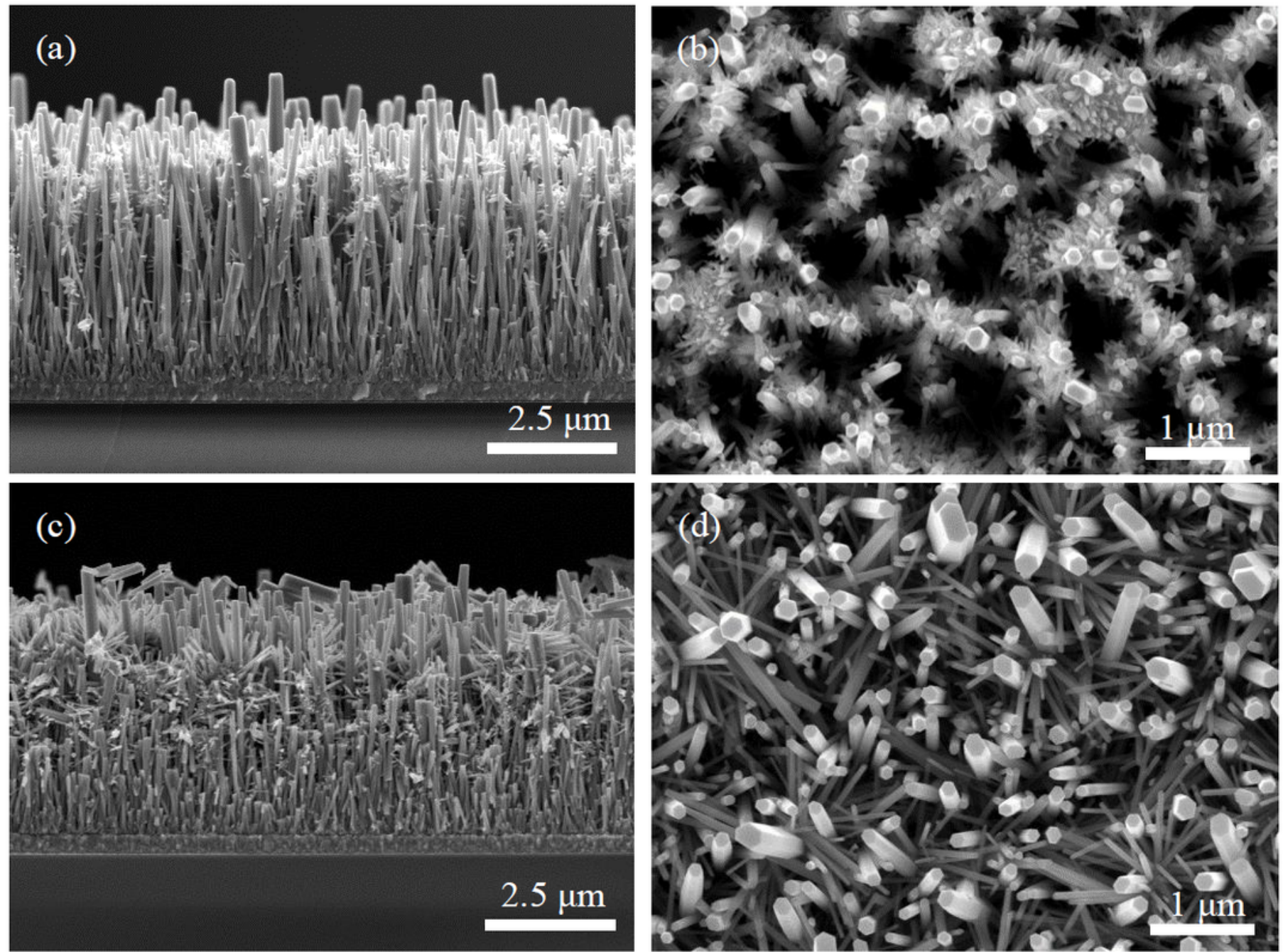

(e)
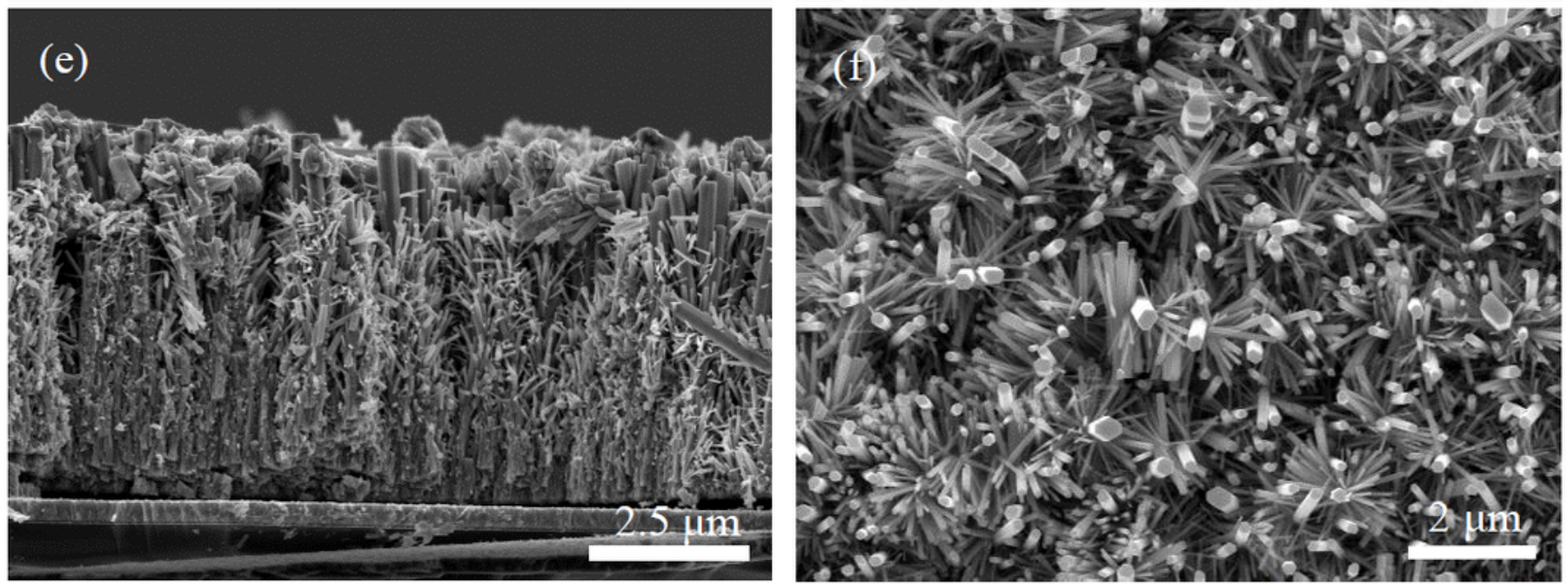

\section{Figure 2}

SEM micrographs of tree-structured $\mathrm{ZnO}$ films prepared at different hydrothermal treatment times, (a) and (b) $1 \mathrm{~h}$; (c) and (d) $6 \mathrm{~h}$; (e) and (f) $12 \mathrm{~h}, 0.12 \mathrm{M} \mathrm{Zn}(\mathrm{CH} 3 \mathrm{COO}) 2$ seed precursor solution 

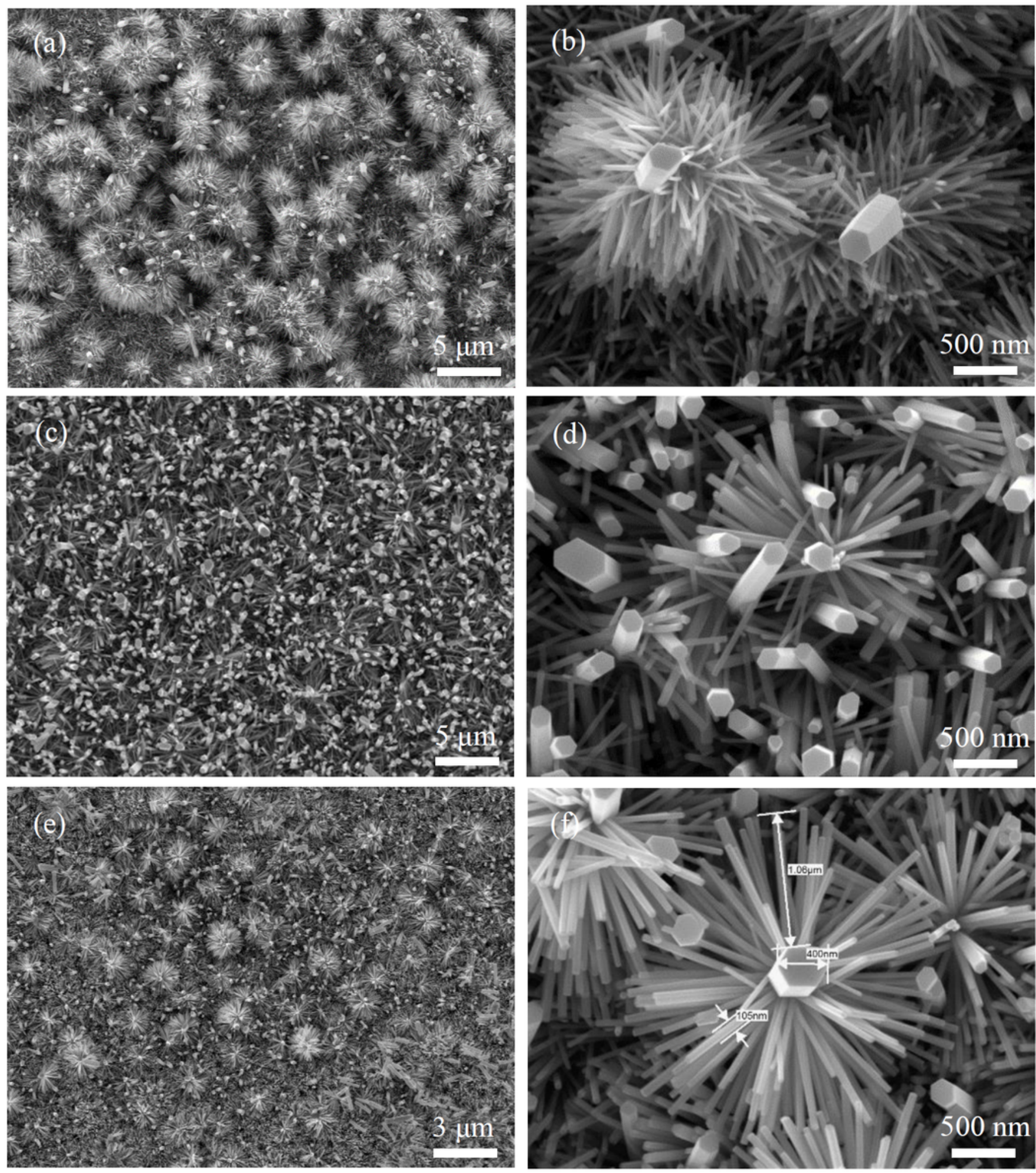

\section{Figure 3}

SEM micrographs of tree-structured $\mathrm{ZnO}$ films prepared with different concentrations of $\mathrm{Zn}(\mathrm{CH} 3 \mathrm{COO}) 2$ in the seed solution, (a) and (b) $2.4 \mathrm{M}$; (c) and (d) $1.2 \mathrm{M}$; (e) and (f) $0.04 \mathrm{M}$. 

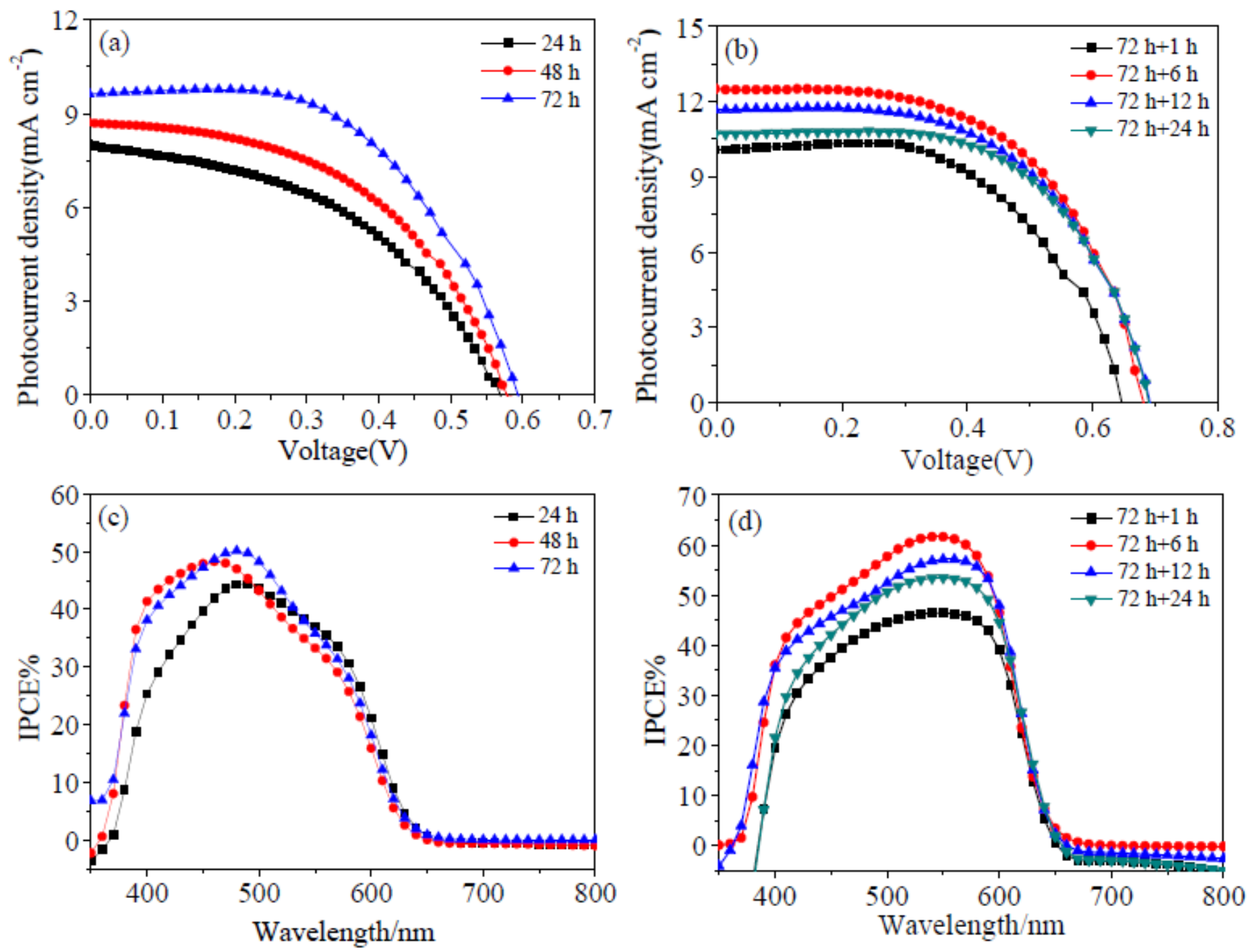

Figure 4

Photocurrent density-voltage and IPCE curves of QDSCs using CdS-CdSe quantum-dot-sensitized ZnO NWs ( $a$ and $c$ ) and tree-structured ZnO films (b and d) as photoanodes.

\section{Supplementary Files}

This is a list of supplementary files associated with this preprint. Click to download.

- ElectronicSupplementaryInformation2.docx 